\title{
Article \\ Evaluation of Implementation of Biomass and Solar Resources by Energy Systems in the Coal-Mining Areas of Spain
}

\author{
Beatriz M. Paredes-Sánchez ${ }^{1, *}$, José P. Paredes-Sánchez ${ }^{1}$ and Paulino José García-Nieto ${ }^{2}$ \\ 1 Department of Energy, College of Mining, Energy and Materials Engineering, University of Oviedo, \\ 33004 Oviedo, Spain; paredespablo@uniovi.es \\ 2 Department of Mathematics, Faculty of Sciences, University of Oviedo, 33007 Oviedo, Spain; \\ pjgarcia@uniovi.es \\ * Correspondence: uo19070@uniovi.es
}

check for updates

Citation: Paredes-Sánchez, B.M.; Paredes-Sánchez, J.P.; García-Nieto,

P.J. Evaluation of Implementation of Biomass and Solar Resources by Energy Systems in the Coal-Mining Areas of Spain. Energies 2022, 15, 232. https://doi.org/10.3390/en15010232

Academic Editor: Changkook Ryu

Received: 26 November 2021

Accepted: 28 December 2021

Published: 30 December 2021

Publisher's Note: MDPI stays neutral with regard to jurisdictional claims in published maps and institutional affiliations.

Copyright: (C) 2021 by the authors. Licensee MDPI, Basel, Switzerland. This article is an open access article distributed under the terms and conditions of the Creative Commons Attribution (CC BY) license (https:/ / creativecommons.org/licenses/by/ $4.0 /)$.

\begin{abstract}
Energy demand is steadily growing as society becomes more industrialised. Renewable energy sources (RES) have long been used for various applications by thermal energy systems in the European Union (EU). Biomass and solar energy represent important RES in the development of energy transition in some regions such as coal-mining areas of Europe. Bioenergy is a key renewable energy storage mechanism for solar energy which, when combined, can tackle many of the barriers to the use of solar energy. Against this background, this study evaluates the potential implementation of both biomass and solar energy for energy production in coal-mining areas in Spain as a direct alternative to coal. The shown methodology relies on a comprehensive analysis of existing resources and their conversion to thermal energy from a multi-parametric point of view. The obtained results show that the solar-biomass combination can be used for thermal energy systems as a challenging option. The theoretical total hybrid-modular systems if implemented in the study area are equivalent to $1165 \mathrm{MW}_{\text {th }}$ and supply thermal energy for 170,000 single-family houses.
\end{abstract}

Keywords: bioenergy; biomass; solar energy; zero-emission energy system; mining areas; Spain

\section{Introduction}

Increasing the use of renewable energy sources (RESs) is an objective towards fostering economic development, improving energy security as well as protecting the world climate [1]. The study areas are often characterised by energy dependence on fossil fuels that are bound to a logistical infrastructure of supply, conversion, and management fully integrated with their industry. A major problem associated with the use of fossil fuels is their greenhouse gases (GHGs), i.e., mainly $\mathrm{CO}_{2}$ and other harmful gases, such as $\mathrm{NO}_{2}$ or $\mathrm{SO}_{2}$. Alternative methods are proposed for reducing anthropogenic gas emissions by burning fossil coal [2-4]. The global energy transition that is inexorably developing worldwide for global warming, environmental, technological, social, and economic reasons, poses a great challenge, but at the same time, it is a great opportunity.

Exploring how to convert RES into alternative thermal energy to coal is a major factor to achieve an efficient energy conversion. Thus, using RES, particularly biomass, for heat rather than electricity production relies on higher energy conversion efficiency, resource availability, and lack of constraints set by regulatory regimes $[5,6]$. Solar energy is dependent on other RES, such as biomass, as a thermal energy source given its daily intermittency and seasonal cycles, which affects continuity energy supply [7]. Any energy system is primarily designed to ensure that the supply of energy services to the end-user is uninterrupted.

The thermal energy systems in buildings have a high potential to contribute to the expansion of RES because they are responsible for almost $36 \%$ of the world final energy and $40 \%$ of $\mathrm{CO}_{2}$ emissions. The integration of energy systems to supply thermal energy has pushed the frontier of knowledge of energy systems development by confronting the 
challenges posed by intermittent solar irradiation and cyclic biomass production [8-13]. Mahmoud et al. [14] have explored the combined use of biomass and solar energy to reduce the environmental impact of energy production compared to conventional systems. Fernandez et al. [15] also illustrated the importance of using forest biomass along with the solar resource as the main source of thermal energy production. Ma et al. [16] looked at the need for developing technology for thermal generation systems for heat networks. Additionally, Mouaky and Rachek [17] developed scenarios for solar and biomass integration from an energy conversion and management point of view, together with the importance of thermal energy production. Finally, Díaz-Cuevas et al. [18] demonstrated that RES resource availability is a key aspect for the direct implementation of thermal energy systems. Resource availability, technology, and energy conversion were identified as the main barriers [19-22] These systems have a global market that is different from conventional systems, which can greatly influence their energy performance due to impacts on the solar-biomass combination. Therefore, assessing hybrid systems for their deployment requires multi-parametric modelling such as fossil fuel mining regions, since these areas facilitate the integration of resource, energy conversion, and energy management [23-26]. Furthermore, modelling requires a detailed and full assessment of the energy production cycle $[16,27,28]$.

For all the reasons specified above, this paper looks at the integration of biomass and solar energy through a multi-parametric analysis, using a processing model of analytical classification of the synergies between resource, conversion, and energy management. The study area is the coal mining regions of Spain, suppliers of energy resources, within a transition energy context, required by European Union (EU) regulations. An important novelty of this study is to assess the amount of energy available by evaluating how feasible it is to combine biomass and solar energy as a primary source, regardless of the nature of the thermo-energy availability. In addition, it also analyses the usability of these sources in terms of self-sufficiency and stable thermal supply within a specific coal mining territory, as an alternative to coal, taking into account the existing technical and environmental conditions in such areas. A further novelty is to be able to provide energy self-sufficiency in remote fossil fuel-producing areas or regions in the world.

This work is organised as follows: Section 1 introduces the research background and the aim of the work. Section 2 explains the research context and methodology used in the modelling process to combine biomass-solar in the study area. Section 3 shows both the results and the details of its application. Section 4 provides a detailed multi-parameter analysis of the use of biomass and solar energy in energy systems. Section 5 summarises the main findings of the study on the use of solar and biomass energy in the coal mining areas of Spain.

\section{Materials and Methods}

\subsection{Research of Biomass and Solar Energy}

Thermal systems based on biomass and solar energy have been studied for various parts of the world [29-31]. The combination of energy systems based on biomass and solar has shown efficiency with thermal energy production [31]. These studies emphasise that the multi-parametric evaluation context is critical for efficient energy management, where the design for a hybrid solar heating plant minimises thermal energy storage. Thus, to improve energy conversion, it is furthermore necessary to analyse the potential contribution of different local RES for direct energy management by energy systems.

Coupling biomass and solar energy as hybrid resources require a stable energy supply environment to minimise potential negative impacts. The hybridisation of biomass combustion with solar thermal complements each other to overcome their management drawbacks $[29,30]$. Additionally, this type of energy supply is continuous and uniform. The main research challenge results from their management and performance, establishing techniques for accurately predicting their output and reliably integrating them.

Hybrid plants will become an increasingly attractive option as the cost of biomass feedstock and solar thermal decrease while fossil fuels continue to rise. In this sense, it 
could be possible to increase biomass savings up to where solar participation in the thermal energy supply has a key role in operation [32]. The viability in each location depends rather on its financial performance and its ability to manage the risks facing it, which are to be assessed separately and take into account the local context and energy business environment. The ultimate economic viability of potential implementation projects depends on the local conditions of the final promotion.

\subsection{Study Area}

As with the rest of the EU, Spanish coal has always faced difficulties with competing in the international market and received significant state subsidies. Many industries, e.g., iron and steel, energy, etc., use coal as raw material. Spanish mining areas have traditionally been known for their poor economic diversification; this gives rise to entire logistic chains of coal extraction, transport, and conversion, which are, by the way, well established and technologically consolidated. During the last decades, mining and the use of coal for heat generation as a primary energy source has taken up most of the economic activities within these mining areas, leaving little space for the development of other alternative resources. This study focuses on the seven mining regions of Spain, as shown in the map below (Figure 1).

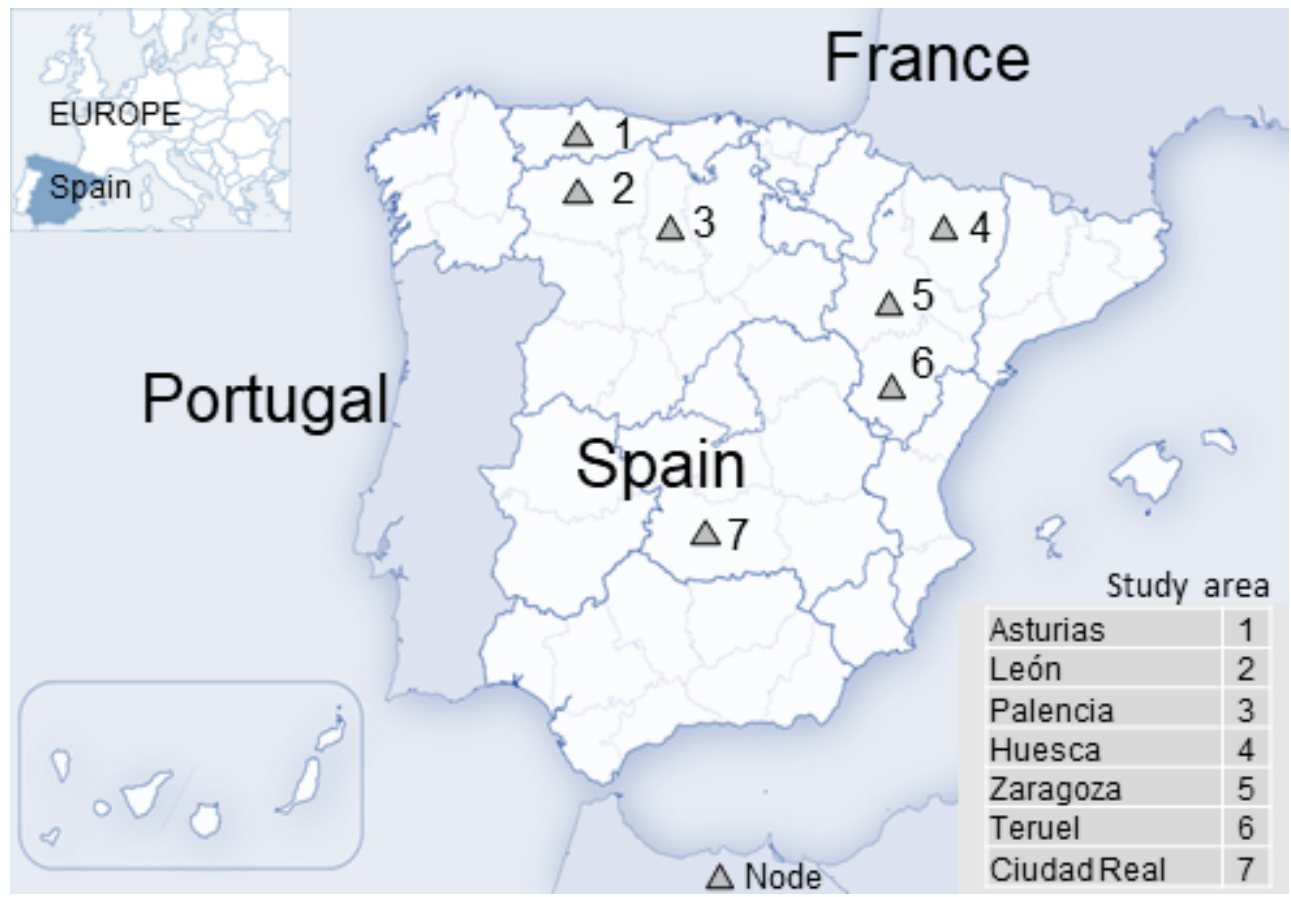

Figure 1. The study area of the coal mining regions areas of Spain.

At present, coal mining and associated industrial activities are located in the following territories: Asturias; León and Palencia (Castilla y León); Huesca, Zaragoza, and Teruel (Aragón); and Ciudad Real (Castilla la Mancha) [33,34] (see Table 1).

\subsection{Multiphase Mathematical Model}

Solar energy combined with biomass exhibits direct integration capability for thermal purposes as an alternative to coal for the production of storable, stable, and time-efficient energy supply. Therefore, the following methodology is presented to calculate biomass/solar resource potential for energy purposes; it defines energy management nodes in the stated territories. Using nodal networks for RES modelling enables the assessment of biomass resources in detail when implementing that type of energy system in a study area $[5,26]$. The multiphase mathematical model developed for this work comprises three phases in the area 
of study: resources, thermo-energetic conversion system, and energy management [5,35,36], as described in Figure 2.

Table 1. Definition of the node code and the sectors in the study area, as Figure 1.

\begin{tabular}{cc}
\hline Node Code & Name of the Sector \\
\hline SA1 & Asturias \\
SA2 & Ciudad Real \\
SA3 & Huesca \\
SA4 & León \\
SA5 & Palencia \\
SA6 & Teruel \\
SA7 & Zaragoza \\
\hline
\end{tabular}

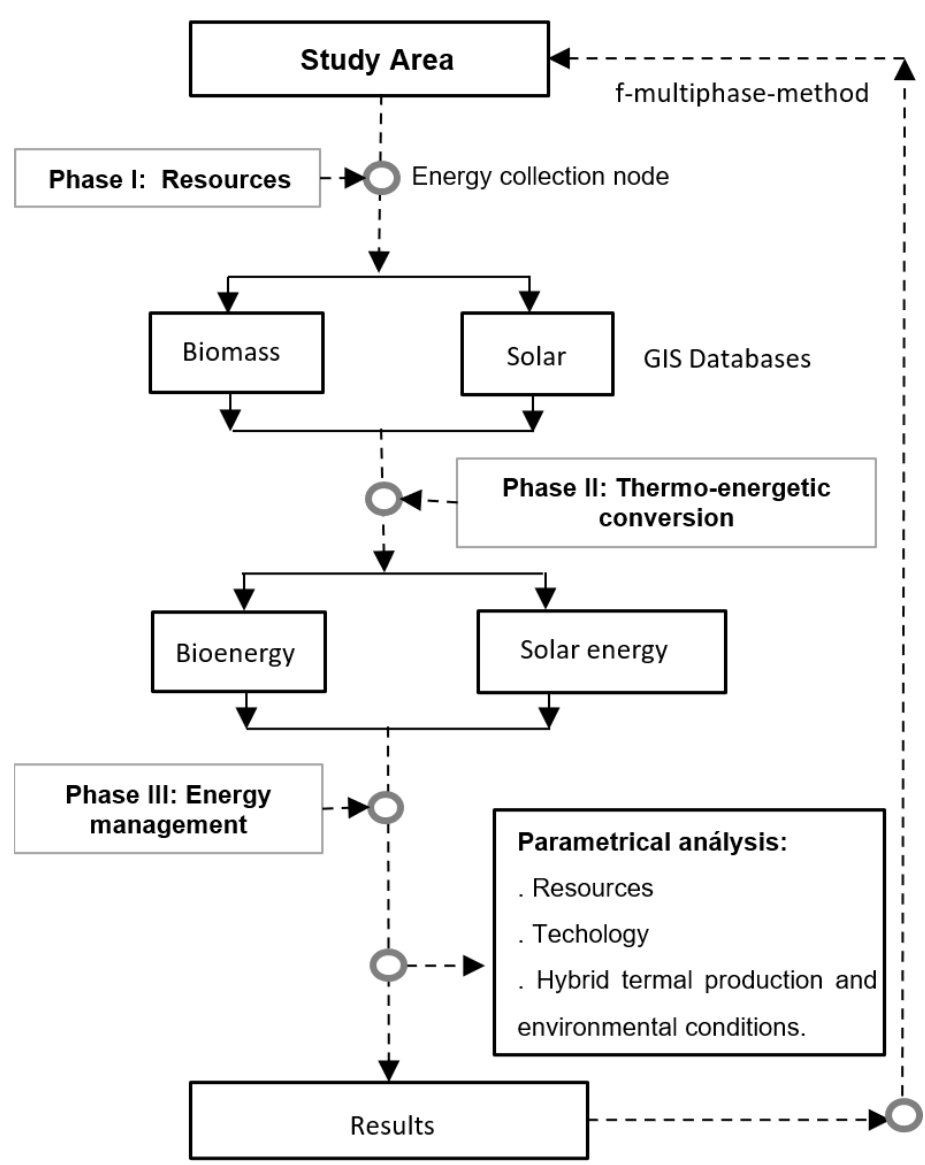

Figure 2. Flowchart of the multiphase mathematical algorithm through mass and energy balance in the study area for biomass and solar energy-based system.

\subsubsection{Phase I: Biomass and Solar Energy Resources}

The RES is analysed as a primary resource to generate the thermal energy form of energy conversion, i.e., heat, on different studies based on bioenergy $[25,36]$. Several researchers have assessed the potential of RES for various regions using Geographic Information System (GIS) tools [37,38]. However, the challenges posed by the energy transition in certain environments require a search for efficient, straightforward alternatives to the existing energy systems for the optimal management of indigenous fossil energy resources. Accordingly, biomass as an alternative to coal appears to be the best way to be used, either in thermal applications or as raw material in the energy industry [39]. Additionally, integrating the natural cycle of biomass with solar energy reveals synergy that facilitates their combined use employing new methodologies. Solar energy could be used for immediate 
utilisation, such as water heating or heat storage [11]. The Photovoltaic Geographical Information System (PVGIS) is a database application that allows the user to obtain solar radiation data at a given location [40-43]. This information enables the assessment of solar resource potential in the study area. For the evaluation of potential resources, the GIS database is taken as a starting point-the BIORAISE GIS tool of the Research Centre for Energy, Environment and Technology (CIEMAT) — which provides data on forest biomass in the vicinity of each of the nodes considered in the study area [44].

To analyse the RES, the novel "f-multiphase-method", "f-method-p", evaluates fractions of the total heating load supplied by RES to meet the energy demand. The model proposes dimensionless parameters called "f-factors" for each type of RES.

Forest biomass is one of the main resources for thermal bioenergy in mining areas because of the potential energy conversion as a primary resource, and its integrability in the industrial energy supply chains $[9,24,27]$. To select the most suitable location for resource assessment in each sector of the studied area (Figures 1 and 2), a collection area is defined for forest biomass according to the borderline of each coal region of Spain $[25,26]$. The collection area is the geographic surface inside the regional borderline [44].

Information on the potential forest biomass in the study area can be used to calculate the available biomass by including several environmental constraints, including energy content to define the potential access to the resource as the biomass distribution, production, and location by GIS tool $[44,45]$.

The potential mass $(\mathrm{M})$ is the forestry residues, i.e., branches and leaves, found within the study area. The available mass $(\mathrm{m})$ includes branches and tops including leaves. It is obtained from the BIORAISE GIS database by cleaning, thinning, and felling operations data (Figure 2), which takes into account the techno-economic constraints of the biofuel supply to define the useful resources. The software assigns an average productivity value (taken from yield tables of different forest species) to each of the Corine Land Cover categories [44]. In a specific way, it is possible to achieve a centralised energy conversion of the largest amount of the available resources in each area. This procedure will allow this location to be characterised as a resource evaluation node. Techno-economic constraints affect bioenergy supply depending on the supply biofuel conditions [44,45]. The available biomass resources include conifers, wood, and mixtures. Available biomass is evaluated in the surroundings of the selected node in each regional area, as shown in Equation (1).

$$
\mathrm{m}=\sum_{\mathrm{i}=1}^{\mathrm{n}} \mathrm{m}_{\mathrm{i}}
$$

where:

$\mathrm{m}$ : total available mass (dry $\mathrm{t} /$ year).

$\mathrm{m}_{\mathrm{i}}$ : total available mass of conifers, hardwood, and mixtures (dry $\mathrm{t} / \mathrm{year}$ ).

The resulting energy from the available residues (E) is shown in Equation (2), where the Lower Heating Value (LHV) is used.

$$
\mathrm{E}=\sum_{\mathrm{i}=1}^{\mathrm{n}}\left(\mathrm{m}_{\mathrm{i}} \cdot \mathrm{LHV}_{\mathrm{i}}\right)
$$

where:

E: energy from available mass (GJ/year).

$\mathrm{m}_{\mathrm{i}}$ : total available mass of conifers, hardwood, and mixtures (dry $\mathrm{t} /$ year).

$\mathrm{LHV}_{\mathrm{i}}$ : Lower Heating Value of conifers, hardwood, and mixtures (GJ/dry $\mathrm{t}$ ).

Solar energy is one of the most important resources for thermal applications in Spain [7]. For solar energy, PVGIS is used as a reference to define average daily radiation as a solar energy resource in the study area (Figure 1) $[7,41,42]$.

\subsubsection{Phase II: Thermo-Energetic Conversion}

The overall RES potential in Spain is greater than total domestic demand, including fossil fuels [46]. Despite this situation, Spain is highly dependent on fossil fuel imports. 
Coal is the main indigenous resource for energy generation [47]. However, this situation is changing as coal is rapidly being phased out.

The technological capacity of the Spanish energy industrial sector is at the forefront to use RES to generate electricity and/or heating [48]. There is ample literature; e.g., Saint-Marc et al. [6] analysed forest biomass electricity production in Spain. With available resources and energy system parameters, a techno-economic parametric model was applied to show the potential of biomass production and the barriers to electricity generation. This demonstrated the challenge of the non-viability posed by this type of power plant in the current context, even after using energy crops. In this sense, Paredes-Sánchez et al. [5] demonstrated that the main application for bioenergy implementation is thermal energy in mining areas. The management of sustainable energy systems will play a key role in district heating systems (DHS) for future thermal energy in Spain in the areas under study. This would require a careful balancing between thermal energy generated, the sum of energy consumed, and heat losses. Typically, shares of the solar district heating can be categorised into centralised and distributed systems. Centralised systems include a largescale ground-mounted solar field, typically coupled with a thermal energy storage system, whereas distributed (solar panels) systems are located on rooftops of single buildings to supply their heat demand $[49,50]$.

Hybrid energy systems based on RES are emerging to meet new challenges with a high level of efficiency. Hybrid-modular types of equipment are versatile and can combine different types of energy sources in the supply chain. For example, they can provide a heating load for energy processes during the fluctuation or nonavailability of some RES. One of the main environmental benefits of DHS is its ability to significantly reduce $\mathrm{CO}_{2}$ emissions owing to RES energy conversion technology. Special attention should be paid to the management of thermal energy to reduce their carbon footprint and GHG, which is a key to the success of DHS networks to find the right balance between technical and environmental aspects. Solar district heating represents $10-50 \%$ of this total heat supply. Without heat storage, solar district heating can supply $10-30 \%$ of the annual demand depending on the annual distribution of the solar radiation and the heat load [51].

The "F-chart method" is used as an empirical framework to characterise the longterm performance of solar heating systems [52]. It is based on f-chart methodology as approximations of model results fitted to the pair of $X$ and $Y$ values for the solar system. It correlates those parameters with thermal performance where parameter $f_{s}$ is presented as a function of two dimensionless parameters $X$ and $Y$ as defined in Equations (3) and (4), respectively.

$$
\begin{gathered}
\mathrm{X}=\text { Collector Energy Losses/ Heating Load } \\
\mathrm{Y}=\text { Energy Absorbed by Collector/Heating Load }
\end{gathered}
$$

In terms of collector properties, those values can also be expressed as follows, as the base model [52-55], whose metrics are normally defined per month. The proposed model is based on (Equations (5) and (6)):

$$
\begin{aligned}
& X=F_{R} U_{L} \cdot \frac{F \prime_{R}}{F_{R}} \cdot\left(T_{\text {ref }}-\bar{T}_{a}\right) \cdot \Delta t \cdot \frac{A_{c}}{L} \\
& Y=F_{R}(\tau \alpha)_{n} \cdot \frac{F / R}{F_{R}} \cdot \frac{(\bar{\tau} \alpha)}{(\tau \alpha)_{n}} \cdot \bar{H}_{T} \cdot N \cdot \frac{A_{c}}{L}
\end{aligned}
$$

All the parameters and properties used in this model are available from collector tests and operational conditions, where:

$\mathrm{A}_{\mathrm{c}}=$ Area of solar collector area $\left(\mathrm{m}^{2}\right)$.

$\mathrm{F}_{\mathrm{R}}^{\prime}=$ Collector-heat exchanger efficiency factor $(\%)$.

$\mathrm{F}_{\mathrm{R}}=$ Collector heat removal factor $(\%)$.

$\mathrm{U}_{\mathrm{L}}=$ Collector overall energy loss coefficient $\left(\mathrm{W} / \mathrm{m}^{2} \cdot{ }^{\circ} \mathrm{C}\right)$.

$\Delta \mathrm{t}=$ Total number of seconds in the month. 
$\overline{\mathrm{T}}_{\mathrm{a}}=$ Monthly average ambient temperature $\left({ }^{\circ} \mathrm{C}\right)$.

$\mathrm{T}_{\text {ref }}=$ Empirical reference temperature $\left({ }^{\circ} \mathrm{C}\right)$.

$\overline{\mathrm{H}}_{\mathrm{T}}=$ Monthly average daily radiation incident on collector surface per unit area $\left(\mathrm{J} / \mathrm{m}^{2}\right)$.

$\mathrm{L}=$ Monthly total heating load for space heating and hot water $(\mathrm{J})$.

$\mathrm{N}=$ Number of days per month.

$(\overline{\tau \alpha})=$ Normal transmittance-absorptance product $(\%)$.

$(\tau \alpha)=$ Monthly average transmittance-absorptance product $(\%)$.

The collector and heat exchanger parameters are determined from standard and normalized collector tests. Data on environmental and technical parameters are based on parametrical solar energy databases for each node in the study area [41,42,55]. The model is adapted for energy supply, energy conversion, environmental conditions, and heat storage possibilities [55].

Equations (7)-(9) are the result of model data fitting based on the "f-chart method" [52-54]. In this sense, the proposed hybrid-modular system combines solar and biomass energy. For biomass thermal evaluation, the $\mathrm{f}_{\mathrm{bi}}$ factor defines the contribution per month of biomass supply to the biomass system heating load. Hence, the total biomass fraction $\left(\mathrm{F}_{\mathrm{b}}\right)$ per year can be obtained by the sum of all bioenergy supplies per month (Equation (7)).

$$
\mathrm{F}_{\mathrm{b}}=\sum\left(\mathrm{f}_{\mathrm{bi}} \cdot \mathrm{L}_{\mathrm{i}}\right) / \sum \mathrm{L}_{\mathrm{i}}
$$

For solar thermal analysis, the $\mathrm{f}_{\mathrm{Si}}$ factor is defined as a dimensionless parameter by empirical equation to define the solar coverage of the total heating load per month [52] (Equation (8)).

$$
\mathrm{fs}_{\mathrm{i}}=1.029 \mathrm{Y}-0.065 \mathrm{X}-0.245 \mathrm{Y}^{2}+0.0018 \mathrm{X}^{2}+0.215 \mathrm{Y}^{3}
$$

Furthermore, the total solar fraction of annual heating load $\left(\mathrm{F}_{\mathrm{s}}\right)$ per year can be found by the sum of all monthly fractions (Equation (9)) during the year.

$$
\mathrm{F}_{\mathrm{s}}=\sum\left(\mathrm{f}_{\mathrm{si}} \cdot \mathrm{L}_{\mathrm{i}}\right) / \sum \mathrm{L}_{\mathrm{i}}
$$

Equation (10) for the proposed method fulfils:

$$
\mathrm{F}_{\mathrm{b}}+\mathrm{F}_{\mathrm{s}}=1
$$

Lastly, $\mathrm{F}_{\mathrm{b} / \mathrm{s}}$ analyses the relationship between bioenergy and solar energy supply (Equation (11)).

$$
\mathrm{F}_{\mathrm{b} / \mathrm{s}}=\mathrm{F}_{\mathrm{b}} / \mathrm{F}_{\mathrm{s}}
$$

In addition, this novel method of analysis, "Factorial Method", has been developed to bridge the existing gaps between resources, technology, and management, in hybrid thermal systems. For example, Rämä and Mohammadi [50] compared centralised and distributed systems and concluded that a centralised solution outpaces the distributed systems in terms of performance and management. In Austria, Denmark, Germany, and Sweden, investment in DHS installations has already taken place with similar resource and operation conditions of mining areas of Spain [56]. Solar thermal systems were successfully reported to be for operation in DHS applications and implementations up to or over $350 \mathrm{~kW}_{\text {th }}$ and $500 \mathrm{~m}^{2}$ [57]. Thus, a thermal system is dimensioned as a modular solar-biomass system based on the prototypes studied in the study area for thermal energy production [24,25]. The proposed hybrid-modular system based on the combined use of solar heat and biomass includes mainly a ground-mounted solar field (solar panels) and a biomass boiler as main energy systems (Figure 3) [55,56]. 


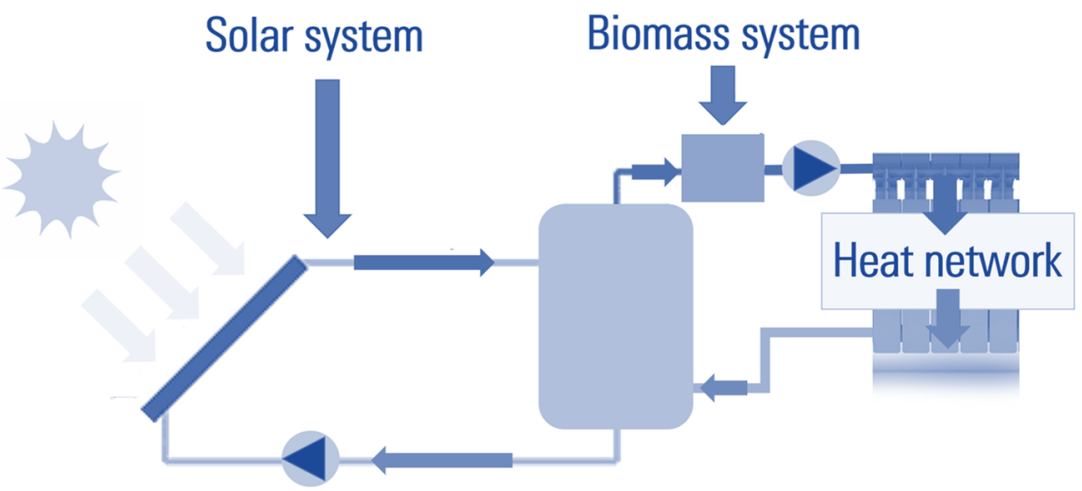

Figure 3. The base structure of the hybrid-modular system.

Figure 3 shows the schematic layout for the hybrid-modular system. The heat source is produced in series by solar and biomass systems. The solar system is based on solar collectors; meanwhile, the biomass system uses a boiler. The hot water source for district heating is obtained from two sources in the daytime. In the nighttime, hot water can be generated only from biomass without stopping. The use of heat exchangers and pumps allow supplying the hot water by a heat network.

Additionally, a control system integrating bioenergy and solar energy is needed to manage the RES conversion to meet energy demand, as shown in Figure 3. Table 2 shows the main characteristics of the proposed energy system.

Table 2. Operational parameters of the hybrid-modular system.

\begin{tabular}{cc}
\hline Main Operation Parameters & Load Data \\
\hline Design power $\left(\mathrm{kW}_{\mathrm{th}}\right)$ & 250 \\
Biomass boiler efficiency $(\%)$ & 80 \\
Base surface of the solar collection $\left(\mathrm{m}^{2}\right)$ & 250 \\
Full-load operation hours $(\mathrm{h})$ & 2000 \\
Biomass /Solar coverage $(\%)$ & $70 / 30$ \\
\hline
\end{tabular}

\subsubsection{Phase III: Energy Management}

Although wood-based resource can be used for the generation of heat and electricity, it remains uncompetitive compared to traditional fossil fuels. Consequently, serious efforts have been made to develop new technology to increase efficiency and compete with fossil fuels. Currently, the main challenges in the area of energy management are technical limitations, viability, social acceptability, and environmental safety. Community initiatives for RES must promote the production and consumption of sustainable energy systems. The present analysis is based on thermal energy production as an alternative from the integration of solar and biomass resources to thermal fossil fuels applications mainly based on coal in the study area $[14,25,58]$.

Biomass represents a manageable and storable RES alternative and should play an increasing role in replacing fossil fuels (Phase III). Based on the analysis of energy management, the generated energy is compared to its energy-based equivalence to the mass $\left(\mathrm{m}_{\mathrm{f}}\right)$ of other conventional fuels (e.g., coal), as shown in Equation (12).

$$
\mathrm{m}_{\mathrm{f}}=\mathrm{E}_{\mathrm{b}} / \mathrm{LHV}_{\mathrm{i}}
$$

This is done by taking the calorific value $\left(\mathrm{LHV}_{\mathrm{i}}\right)$ of the fuels in Table 3 as an approximation [5]. 
Table 3. Fuel properties and composition based on ultimate analysis on dry weight basis [59-62].

\begin{tabular}{cccc}
\hline Parameters & Unit & Wood Fuel & Coal Fuel \\
\hline Carbon & $\mathrm{wt} \%$ & 50 & 82 \\
Hydrogen & $\mathrm{wt} \%$ & 6 & 5 \\
Nitrogen & $\mathrm{wt} \%$ & 0.4 & 2.1 \\
Sulphur & $\mathrm{wt} \%$ & 0.08 & 0.90 \\
Low Heating Value & $\mathrm{MJ} / \mathrm{kg}$ & 17 & 32 \\
(LHV) & & & \\
\hline
\end{tabular}

Note: wt = weight.

Thermal demand is defined by taking into account the consumption of domestic hot water (DHW) and energy requirement of about 12,980 kWh/single-family house per year [63]. The techno-economic analysis depends on the market conditions of demand and supply $[24,25]$. The techno-economic analysis defines the potential individual components (capital investment cost, operating cost, and production cost of the unit). The costs have been defined based on similar systems and the particular conditions of the system [26]. The economic study is based on the analysis of the parameters shown in Table 4.

Table 4. Main parameters of the economic analysis for base scenarios as an approach.

\begin{tabular}{cc}
\hline Parameter & Total \\
\hline Income & \\
\hline Heat price $\left(€ / \mathrm{kWh}_{\mathrm{th}}\right)$ & 0.20 \\
\hline Expenditure & \\
\hline Biomass system $\left(€ / \mathrm{kWh}_{\mathrm{th}}\right)$ & 0.12 \\
Solar system $\left(€ / \mathrm{kWh}_{\mathrm{th}}\right)$ & 0.19 \\
Buxiliary systems and network $\left(€ / \mathrm{kWh}_{\text {th }}\right)$ & 0.23 \\
Biomass supply $(€ / \mathrm{GJ})$ & $5-7$ \\
Operation and maintenance $(€ /(\mathrm{kWh}$ th $\cdot$ year $))$ & 0.09 \\
General expenses $(€ /(\mathrm{kWh}$ th $\cdot$ year $))$ & 0.02 \\
Other $(€ /(\mathrm{kWh}$ th $\cdot$ year $))$ & 0.01 \\
\hline Valuation Parameters & \\
\hline Time Period $($ year $)$ & 15 \\
Discount rate $(\%)$ & 10
\end{tabular}

Note: As an approach, $80 \%$ of the total budget is financed at 15 years with an Annual Percentage Rate (APR) of $6 \%$. Taxes are included, the analysis model considers a Consumer Price Index (CPI) of 3\%.

Three Scenarios have been considered as an approach from Table 4 to analyse the potential evolution of the economic behaviour in the hybrid-modular system with biomass supply cost of $5 \mathrm{GJ} / \mathrm{t}, 6 \mathrm{GJ} / \mathrm{t}$, and $7 \mathrm{GJ} / \mathrm{t}$ to define Scenario 1, Scenario 2, and Scenario 3, respectively.

The constitution of a biomass market in the area will be possible once the necessary instruments of political and economic support have been created for its development. Biofuels improve considerably the potential of biomass for thermal systems. Table 5 provides the employment generation ratios of biomass and solar in each unit by full-time equivalent employees.

Table 5. Estimated ratios by type of job-years per modular hybrid system $[25,26,64]$.

\begin{tabular}{cccc}
\hline System & $\begin{array}{c}\text { Construction and } \\
\text { Manufacturing } \\
(\text { Job-Years/MW }\end{array}$ & $\begin{array}{c}\text { Operation and } \\
\text { Maintenance }\end{array}$ & $\begin{array}{c}\text { Fuel Supply } \\
\text { (Job-Years/MW }\end{array}$ \\
\hline Biomass & 8.5 & 1.5 & 21 \\
Solar & 7.4 & 0.5 & 0 \\
\hline
\end{tabular}




\section{Results}

From Phase I of the multi-objective methodology based on GIS data, the studied locations present a biomass resource potential of $(\mathrm{m})$ from 100 to $340 \mathrm{dry} \mathrm{kt} /$ year with an average availability of $40 \%$. The available resources are equivalent to $11,400 \mathrm{TJ} /$ year $(\mathrm{E})$ in the study area [44]. Figure 4 shows the distribution of available biomass for energy in the different sectors of the area under study (Table 2).

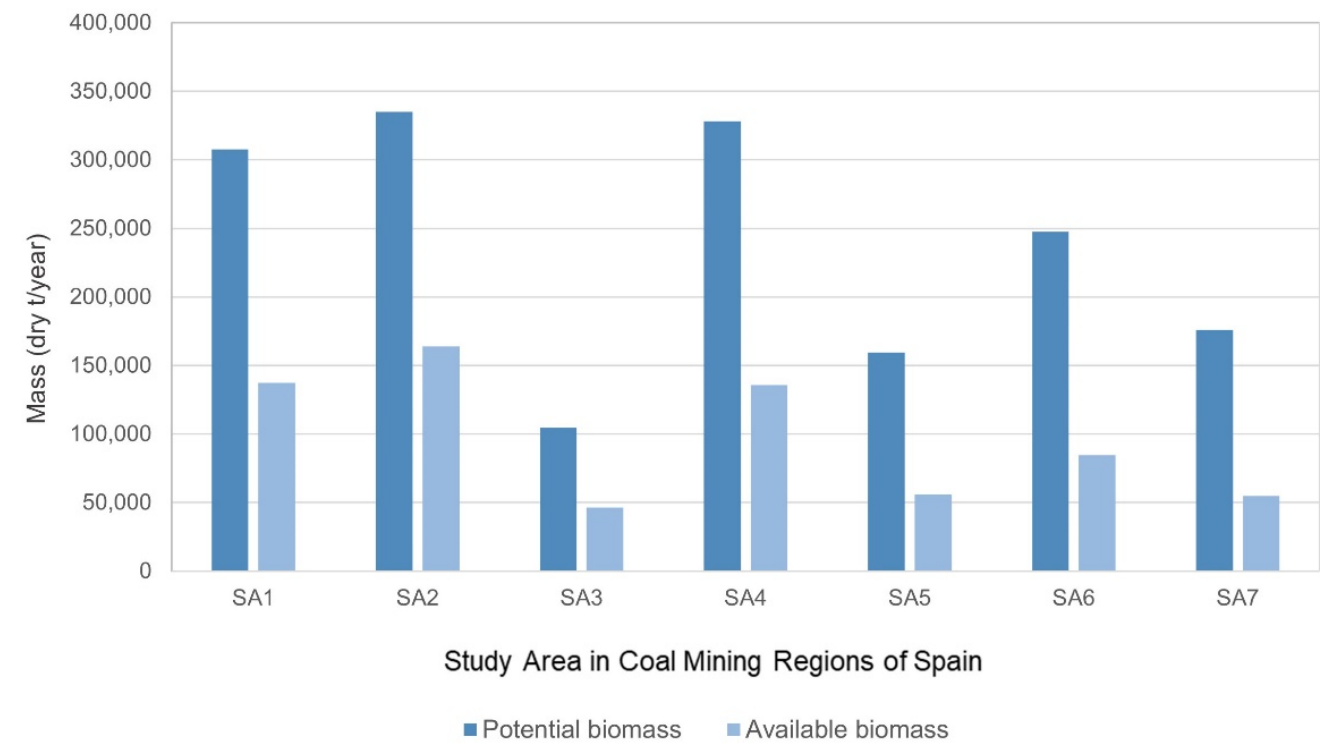

Figure 4. Distribution of the biomass resources in the study area by sector.

Figure 4 presents some linearity in the distribution of the potential biomass around each modelling node considered in Spain.

As for solar energy, the study area shows an average daily solar radiation $\left(\overline{\mathrm{H}}_{\mathrm{T}}\right)$ of $14 \mathrm{MJ} / \mathrm{m}^{2}$ [41,42]. In those conditions, resources are suitable quantitatively and qualitatively for DHS in the proposed conditions [25]. The available solar energy is shown in Figure 5 in the study areas (Table 2).

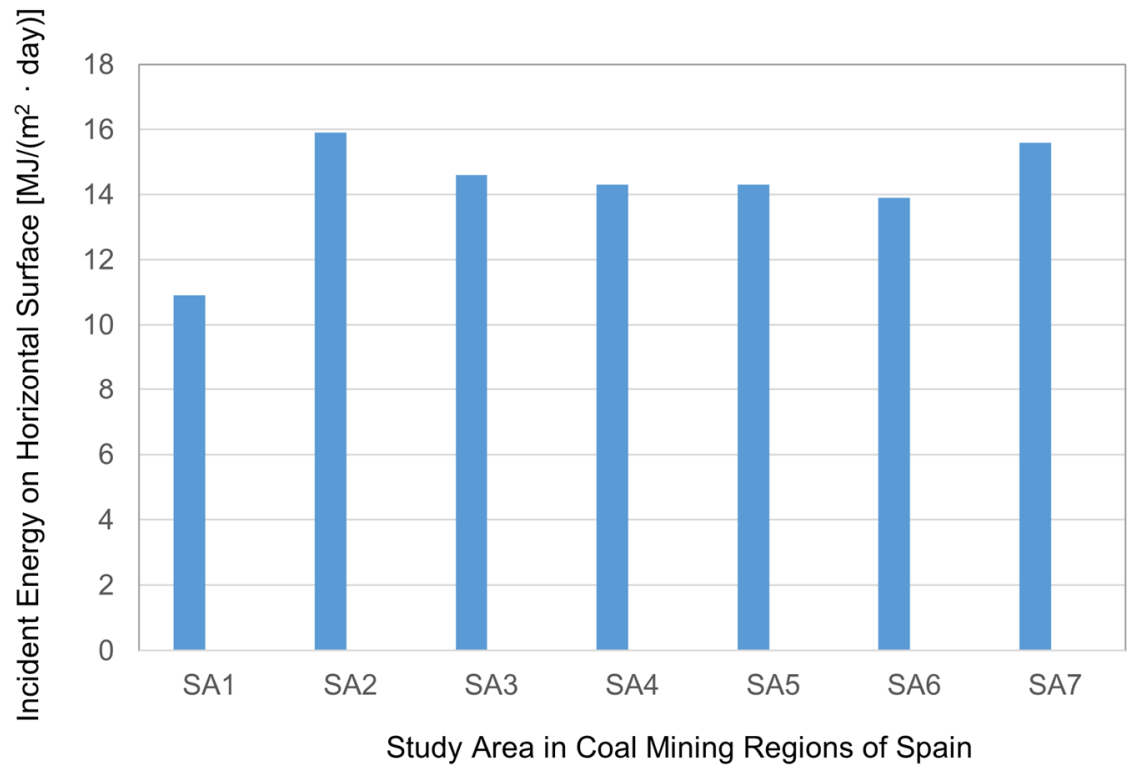

Figure 5. Availability of solar resource in the study area by sector. 
For Phase II, the hybrid-modular system for DHS allows for greater use of RES, i.e., solar and biomass, to provide more efficient energy to meet the heating load. The distribution of the thermal energy demand throughout the year in various study areas is shown in Figure 6 (Table 2).

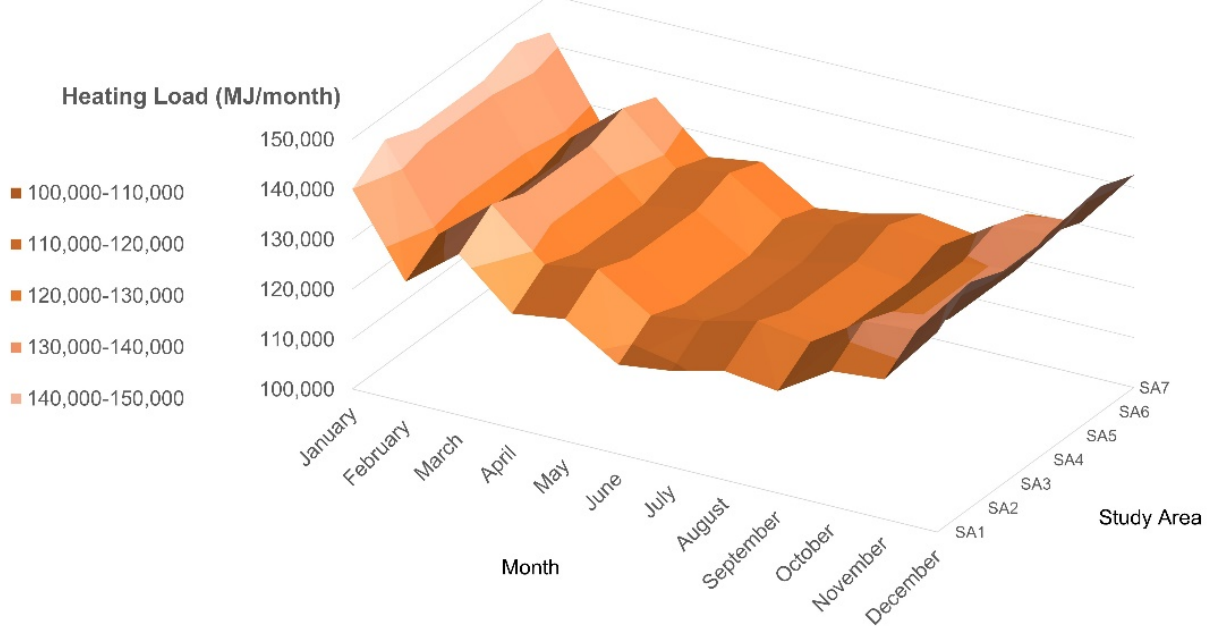

Figure 6. Heating load of the hybrid-modular system per month per sector.

The average total heating load of the hybrid-modular system is about $1700 \mathrm{GJ} /$ year, which has a balanced distribution per month and sector with an average heating load of $130 \mathrm{GJ} /$ month equivalent to 20,000 L/day as DHW at $60^{\circ} \mathrm{C}$ for DHS.

The distribution of bioenergy and solar energy in terms of heating load per month per study area is shown in Figures 7 and 8, respectively.

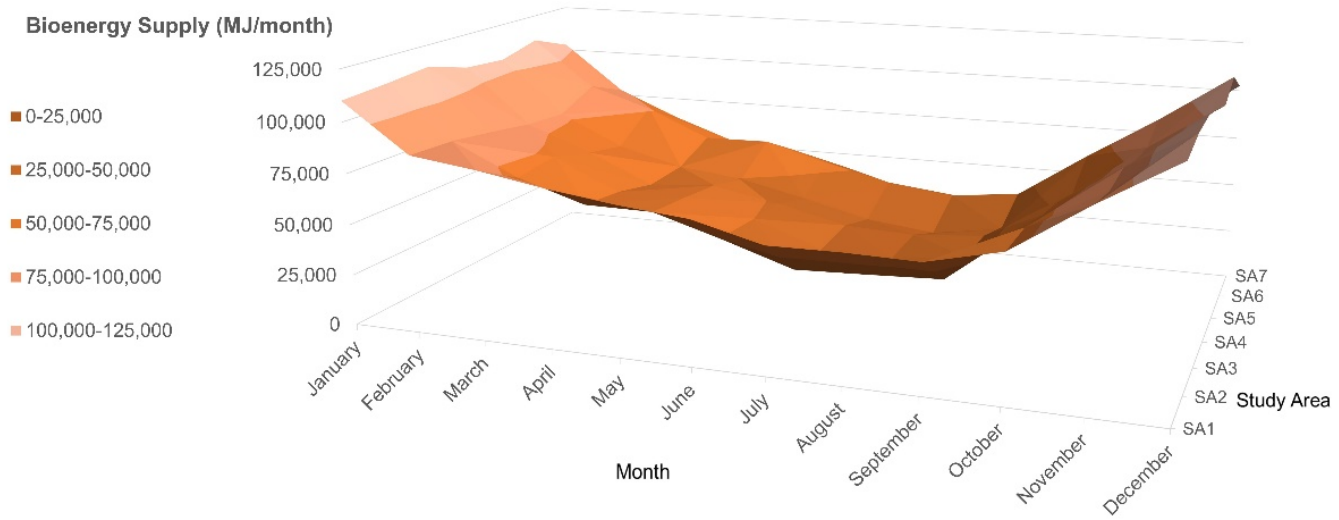

Figure 7. Bioenergy supply in the hybrid-modular system per month by sector.

December has the lowest level of solar energy supply, with an average of $30 \mathrm{GJ} / \mathrm{month}$ per sector, while August shows the highest solar supply, with a total of $85 \mathrm{GJ} / \mathrm{month}$. Bioenergy supply in the proposed modular system provides about $70 \%$ of the total energy supply in any considered area. Bioenergy and solar energy supply are combined with the hybrid-modular system to meet the total heating load.

In connection with Phases II and III, the "f-factors" per month were examined from the point of view of energy management. Figure 9 summarises the outcome of "f-factors" for the total monthly heating load with bioenergy supply being the main contribution (Table 2). 
Solar Supply (MJ/month)

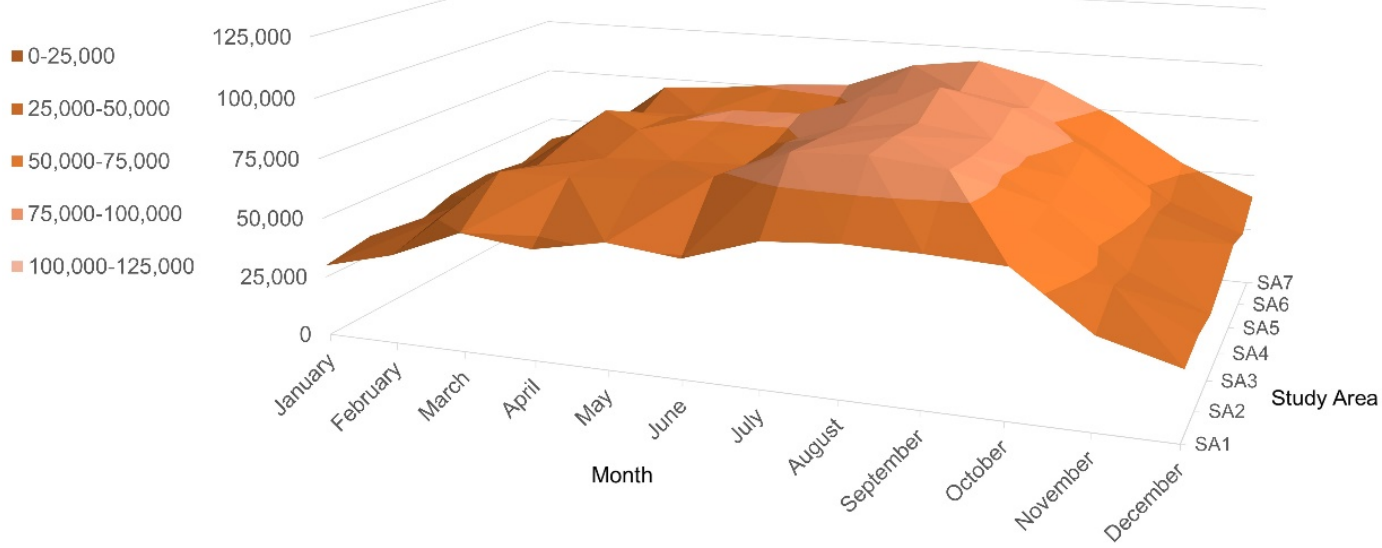

Figure 8. Solar supply in the hybrid-modular system per month by sector.

5

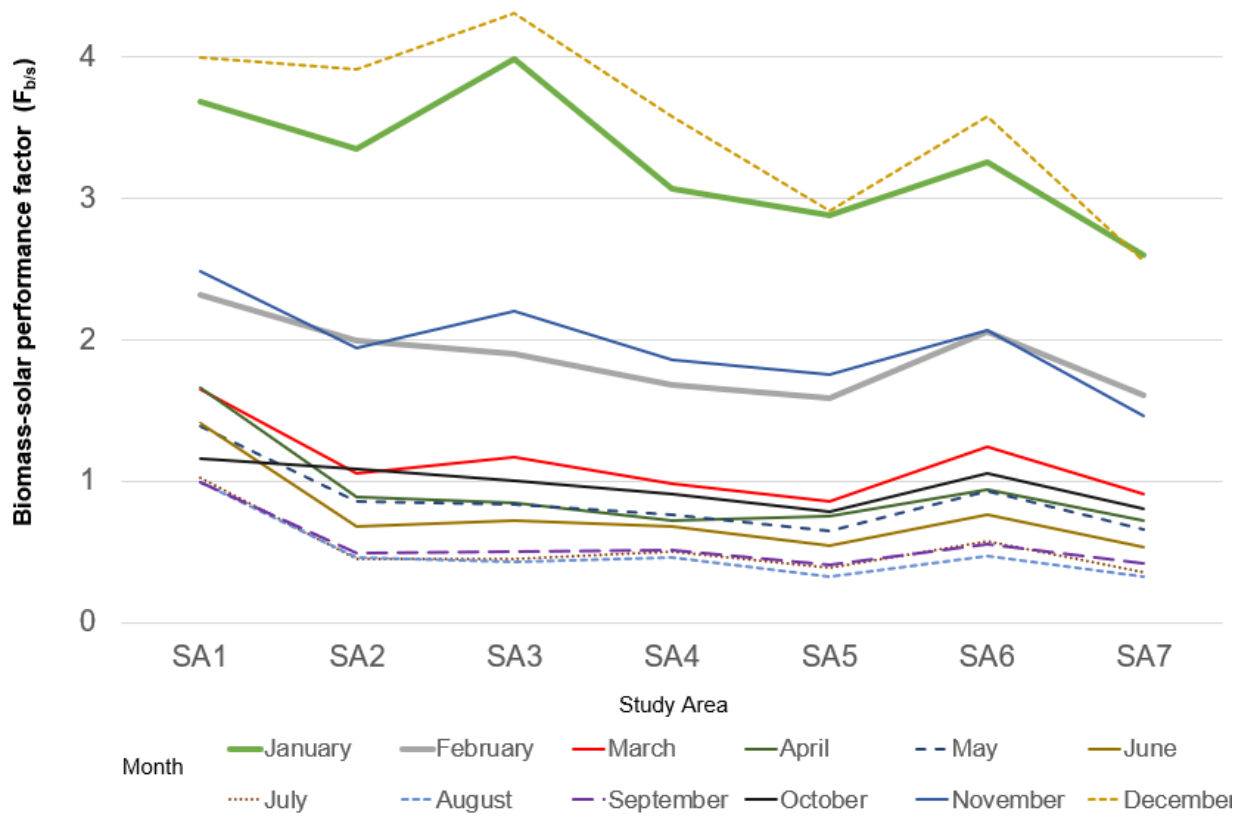

Figure 9. F-factors performance in the hybrid-modular system per month by sector.

The f-factors analyse the combination of bioenergy and solar energy's contribution to supply to meet total heating load with the hybrid-modular system. Additionally, $\mathrm{F}_{\mathrm{s}}$ reflects a minimum average value of 0.2 per month throughout the year. Meanwhile, $F_{b}$ and $F_{b} / s$ average parameters reach up to 0.8 and 3.6 in the same period. These results show the importance of biomass supply.

Finally, energy management evaluation of the modular-hybrid system shows that solar energy contribution to thermal supply is at least 30\% of the total heating load per year. For all these reasons, the analysed method and thermal system have similar parametrical results to thermal systems currently under operation [25,51,65]. Moreover, if the hybrid-modular system is compared with an equivalent coal-based thermal system with $82 \%$ carbon content of coal, a calorific value of $32 \mathrm{MJ} / \mathrm{kg}$ for heating fuel, and a boiler thermal efficiency of $85 \%$ as an pproach, then a coal consumption of $70 \mathrm{t} /$ year and up to $230 \mathrm{t} \mathrm{CO}_{2} /$ year, $3 \mathrm{t}$ $\mathrm{NO}_{2}$ /year, and $1 \mathrm{t} \mathrm{SO}$ /year can be avoided. Additionally, the result of the study shows biofuel consumption by up to $8 \%$ could be reduced with biocoal as the main fuel in the 
hybrid systems [5]. The conversion of biomass into biocoal and biogas production by pyrolysis could be a contribution for the cleaner production of hydrogen $[5,24,39]$.

Additionally, Phase III shows an important contribution to the number of potential hybrid-modular energy conversion systems and power output per study area (Figure 10).

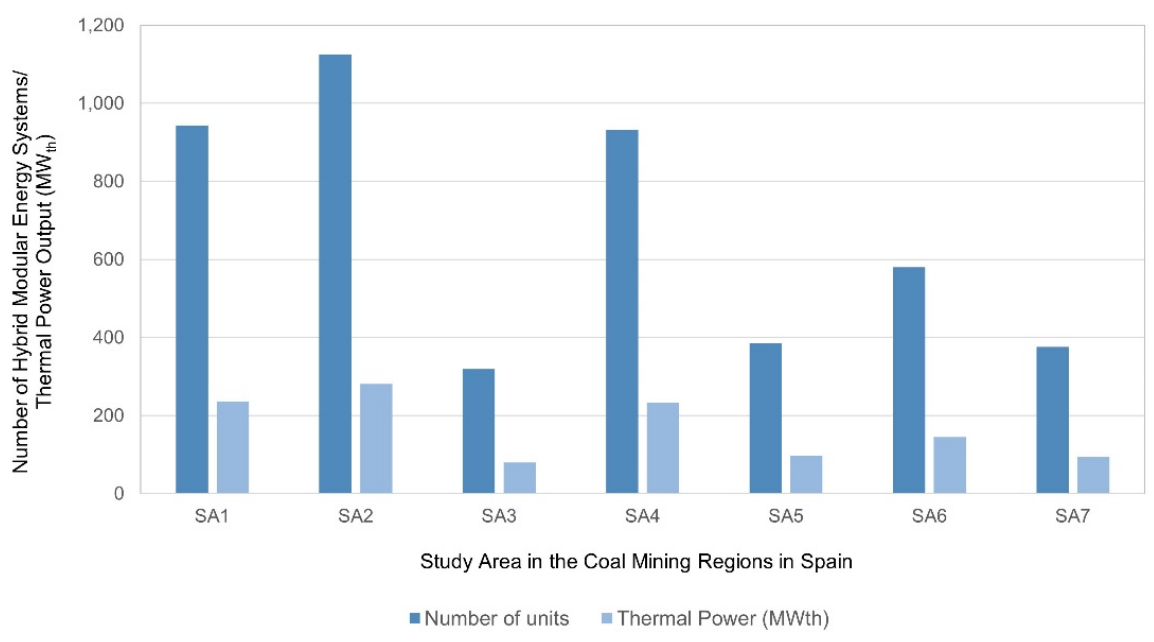

Figure 10. The number of potential hybrid-modular systems and power per sector.

The total potential of hybrid-modular systems is 4661 units for the mining areas of Spain, which are equivalent to $1165 \mathrm{MW}_{\mathrm{th}}$, and they supply thermal energy for 170,000 singlefamily houses. Moreover, these systems could create 28,050 job-years in construction and manufacturing, operation and maintenance, and fuel supply activities (Table 5). The final implementation of the unit systems depends on the particular conditions of each engineering project $[25,51,65]$.

As a future approach, under current market conditions, the biomass is defined by a price of up to $7 € / G J$ by different scenarios (Table 4), which is higher than the total biomass cost in all the study areas. In this sense, the incomes have been minimised; meanwhile, the expenditures have been maximised according to a common model of analysis for the modular-hybrid system in any of the seven study areas. Figures 11 and 12 show the results of the economic model. The interpretation of the model is that the hybrid-modular system will be amortised in a maximum of 7 years. Introducing a subsidy percentage in the total cost of the installation would improve the results obtained (Figure 11).

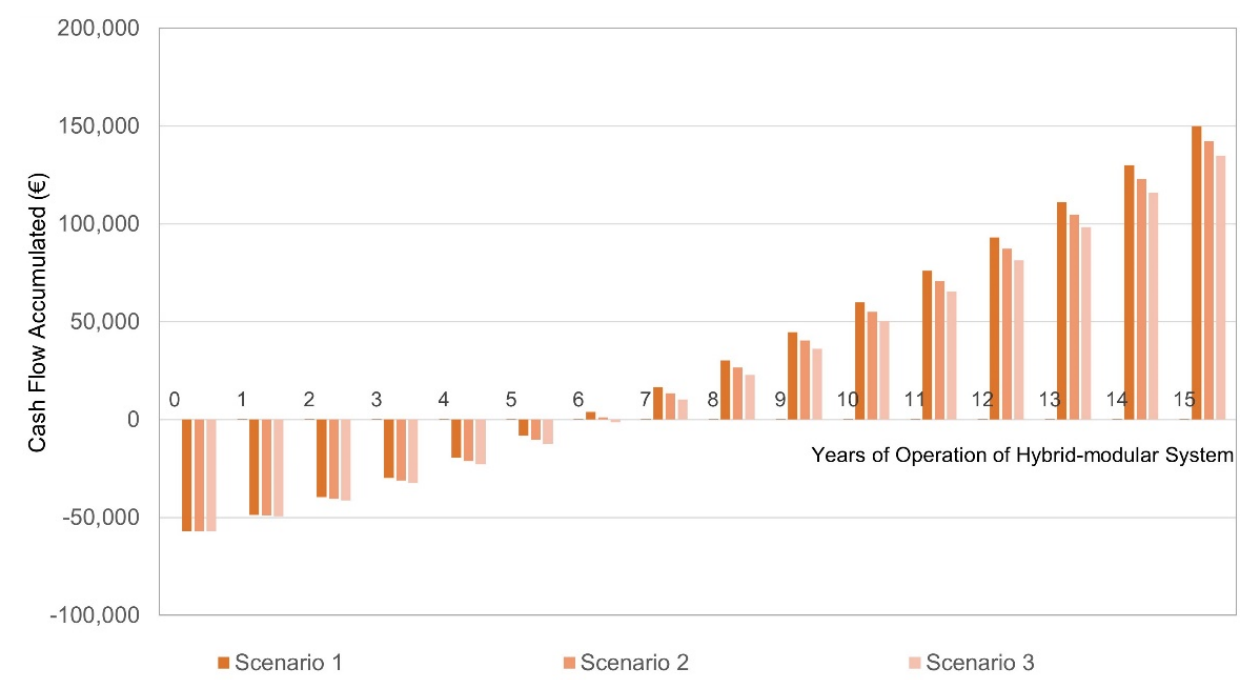

Figure 11. Economic performance approach of the hybrid modular system (in terms of cash flow and cash flow accumulated over a time span of 15 years. 


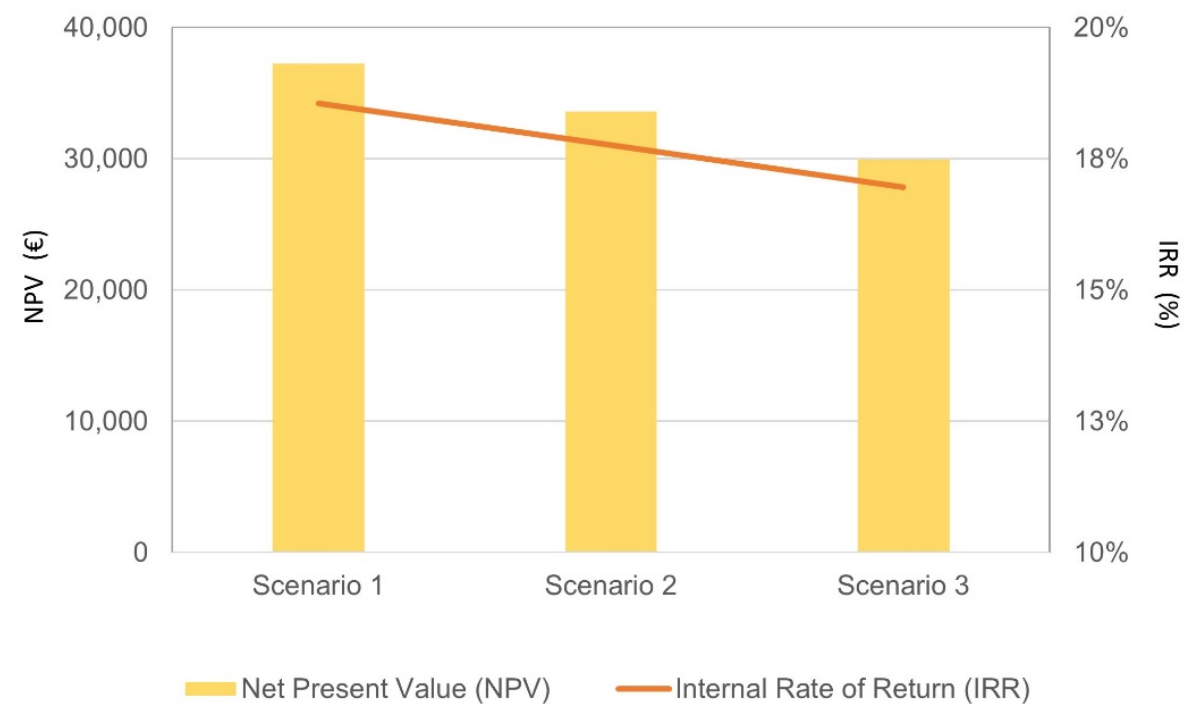

Figure 12. Basis of the economic summary as approach.

Internal Rate of Return (IRR) and Net Present Value (NPV) have been considered for a project life of 15 years as economic performance indicators besides operating requirements of the system with favourable results with the considered conditions with different cost for the biomass supply (Figure 12).

The final viability of these projects will depend on the local implementation characteristics of each study area.

\section{Discussion}

Several reasons have led to closure of coal mining operations in many parts of the EU and the United States, with the consequent job losses over the last few decades. Environmental pressures and improvement of RES technologies had a particular impact. Unquestionably, mining communities are being transformed and require modernising and diversifying their economies. Climate change is putting enormous political pressure on many governments to phase out fossil fuels in general and more specifically coal. Then, coal has no long-term future, and this applies to most of the developed countries. Hence, there is an urgent need to find effective and long-term environmental economic alternatives. Spain is a good example, after government policy is rapidly phasing out coal operations in the country. Therefore, there is an urgent need to find all kinds of alternatives to coal in thermal energy systems.

A key element is the adoption of cleaner energy production targets at the planning level, together with key legislation. This situation is becoming abundantly clear in many places in the world, and particularly in the United States and EU, triggering a post-carbon transition. Implementing a technological alternative requires splitting up the analysis by considering the different aspects involved (Figure 2). Energy integration will be essential to achieve the expected goal in the regional energy systems. The need to combine different resources of energy stems out of the impossibility of satisfying the continuous increase in energy demand for end consumers with alternative sources e.g., solar and bioenergy. The proposed energy system will make it possible for the better use of intermittent RES. The present work demonstrates the importance of combining solar and biomass to provide increasing supply in an environmental and economically more sustainable manner.

RES systems are illustrative of the fact that some of them are at a significant distance from energy demand centres [66]. Overcoming the competitiveness challenge of RES requires careful management and energy supply infrastructure. Different experiences have shown that the sectors linked to the green economy have been protagonists of the energy transition. Indeed, environment improvement and pollution reduction observed in regions, where mining activity has been reduced, are among the positive aspects most highlighted by 
the protagonists of the transitions. Such transition processes have contributed to changing the popular perception of mining regions, being recognised today either as new hubs of technological development, green technology manufacturing, or as production centres for renewable energies.

In general, solar energy systems do not have a direct impact on the environment; however, pollution can occur during manufacturing and maintenance [67]. As a consequence of the mandatory regulations on installation in the Technical Building Code (TBC) of Spain, implementing solar thermal energy in dwellings has become a necessary requirement. In terms of growth prospects, the solar thermal market is strictly linked to TBC, i.e., new housing developments.

Biomass is still the major source of energy in many developing countries. Forest residues are widely used for residential heating, which can cause significant emissions of particulate matter (PM) and other polluting compounds [68-70]. The bioenergy potential in the world is diverse and widely distributed in nature [71]. In addition to environmental benefits, it provides greater energy independence and security of supply, particularly in rural areas. A major problem has been that biomass has been used very inefficiently, except in some industrial countries e.g., Austria and Sweden. Biomass is used in a multitude of applications, from industrial, cottage industries, to households [5]. The demand for biofuels for DHS networks, e.g., chips and pellets, is gradually increasing. DHS are especially common in Scandinavian, Baltic, and Eastern European countries, many of which enjoy a long tradition and can easily adapt to new technologies and applications. For example, Austria, Denmark, Finland, and Sweden use biofuels in solid, liquid, and gaseous forms.

Nowadays, cities have been changing their approach to central heating, raising awareness of its importance while offering solutions that promote energy sustainability. Within this new scenario, urban central heating networks are gaining momentum, encouraged by social change, subsidies, improved technology, lower costs, etc., at local, regional, and even national levels. Central heating networks or "district heating" are typically intended for urban areas in an attempt to establish a circular economic model where the neighbouring rural areas provide the biomass required for the system's operation. In short, biomass DHS networks have several strengths that make them one of the most effective systems for many cities to make the transition to sustainability.

Energy regulations are needed to make room for the development of cleaner energy generation, backed up by business development energy conversion systems [58]. Their environmental strengths include reducing urban pollution, as the plants incorporate hightech emission control systems impossible to install on a stand-alone basis. Their technical strengths consist of flexibility in joining consumers to the grid; simplicity of the installations, as the energy production is common and outside the building; and reliability of the grid, as it reduces equipment maintenance and provides increased control of the system's performance. In addition, there is also the reduction of on-site energy storage in the point of consumption and the reduced noise impact on the building by eliminating fuel storage and handling inside the buildings.

In the future, the study of mining infrastructure as future zones for the use of bioenergy, e.g., biorefineries, makes it necessary for RES and their transformation from a local perspective for regional use. Implementing biomass-solar energy potential requires particular techno-economic and thermal systems, up to an industrial scale based on the specific characteristics and objectives of the facilities under consideration. Finally, to ensure a transition toward more sustainable modes of production and consumption in mining areas, it must guarantee the fulfilment of a series of requirements leading to the efficient use of existing alternative RES. The future industrial and social proposals together with institutional support at local, regional, and national levels are key drivers to new projects. In this sense, the knowledge about biomass as an alternative to biocoal is a challenge. It could have a very positive impact on mining areas in Europe. 


\section{Conclusions}

Technical, environmental, and social issues pressures to reduce the use of fossil fuels, to address climate change, and to ensure the availability of sustainably RES is transforming many mining areas. An understanding of the range of these challenges, when implementing solar and biomass hybrid energy generation systems, under different scenarios, has been shown in a comprehensive and simultaneous assessment. As an approach, this paper has considered solar and biomass as RES options for energy systems. The proposed analysis of the energy model (Figure 2) faces major challenges based on the following main findings:

- The potential biomass resources vary from 100 to 340 dry kt/year with an availability of $40 \%$ in the study area. The total available biomass resources are equivalent to 11,400 TJ/year. Additionally, the study area shows an average daily solar radiation of $14 \mathrm{MJ} / \mathrm{m}^{2}$. Under such conditions, the available resources are sufficient for the proposed energy system.

- Thermal energy is shown as efficient energy conversion in energy systems. A proposed hybrid-modular system combines solar and biomass energy with a techno-economic sustainable manner to produce $250 \mathrm{~kW}_{\text {th }}$ with $70 \%$ of bioenergy supply equivalent to 20,000 L/day as DHW at $60^{\circ} \mathrm{C}$ for DHS. The F-factors analysis by "f-method-p" shows an $F_{s}$ minimum average value of 0.2 per month throughout the year. Meanwhile, $F_{b}$ and $F_{b / s}$ average parameters can be up to 0.8 and 3.6 in the same period.

- The hybrid-modular system could avoid a coal consumption of $70 \mathrm{t} /$ year, and up to $230 \mathrm{t} \mathrm{CO}_{2}$ /year, $3 \mathrm{t} \mathrm{NO}$ / year, and $1 \mathrm{t} \mathrm{SO}_{2}$ /year can be avoided per system considering a total chemical conversion, by combustion, of coal into these types of emissions.

- The theoretical total hybrid-modular systems to implement in all the sectors of the study area (Figure 1) are 4661 units equivalent to $1165 \mathrm{MW}_{\text {th }}$ and supply thermal energy for 170,000 single-family houses, which could create 28,050 job-years.

The results from this study demonstrate the importance and viability of thermal energy as a primary source. Hybrid systems (solar + biomass) are a viable alternative that can maximise energy from source to end-use. The main barriers are technological, legal, and political, which need to be put in place to ensure its further development. The conversion of biomass into biocoal and hydrogen could be a challenge for cleaner production.

Author Contributions: Conceptualization and methodology, B.M.P.-S. and J.P.P.-S.; software, B.M.P.S.; writing-original draft preparation, B.M.P.-S.; writing—review and editing, B.M.P.-S.; visualization, J.P.P.-S. and P.J.G.-N.; supervision, B.M.P.-S., J.P.P.-S. and P.J.G.-N. All authors have read and agreed to the published version of the manuscript.

Funding: This research received no external funding. It is the final part of a doctoral thesis through experimental research about thermal systems at the University of Oviedo.

Acknowledgments: The authors would like to acknowledge the contributions of D. Francisco Rosillo Calle of the Imperial College of London in the development of this research work to conclude a doctoral studies. The authors would like to acknowledge the support of the technical staff of the Research Centre for Energy, Environment, and Technology (CIEMAT) throughout the initial stages of this research work. We would like to thank all the companies and institutions that have contributed in some way to the work described in this paper.

Conflicts of Interest: The authors declare no conflict of interest.

\section{References}

1. Kumar, A.; Sah, B.; Singh, A.R.; Deng, Y.; He, X.; Kumar, P.; Bansal, R.C. A review of multi criteria decision making (MCDM) towards sustainable renewable energy development. Renew. Sustain. Energy Rev. 2017, 69, 596-609. [CrossRef]

2. Stanislav, Y.; Anton, T.; Nikolay, B.; Vladimir, G. Justification of the Energy Use of Cedar Husk Waste as an Environmentally Friendly Additive for Co-Combustion with Coal. Energies 2021, 14, 7027. [CrossRef]

3. Arribas, L.; Lechón, Y.; Perula, A.; Domínguez, J.; Ferres, M.; Navarro, J.; Zarzalejo, L.F.; García Barquero, C.; Cruz, I. Review of Data and Data Sources for the Assessment of the Potential of Utility-Scale Hybrid Wind-Solar PV Power Plants Deployment, under a Microgrid Scope. Energies 2021, 14, 7434. [CrossRef] 
4. Yankovsky, S.A.; Kuznetsov, G.V.; Tolokolnikov, A.A.; Cherednik, I.V.; Ivanov, A.A. Experimental study of the processes of reducing the formation of sulfur oxides during the co-combustion of particles of metalignitous coal and wood processing waste. Fuel 2021, 291, 120233. [CrossRef]

5. Paredes-Sánchez, B.M.; Paredes-Sánchez, J.P.; García-Nieto, P.J. Energy Multiphase Model for Biocoal Conversion Systems by Means of a Nodal Network. Energies 2020, 13, 2728. [CrossRef]

6. Saint-Marc, R.; Paredes-Sánchez, J.P.; Xiberta-Bernat, J. Power Generation from Bioenergy Crops by Technical and Economic Feasibility Assessment. Proceedings 2018, 2, 1476. [CrossRef]

7. Paredes-Sánchez, J.P.; Las-Heras-Casas, J.; Paredes-Sánchez, B.M. Solar Energy, the Future Ahead. In Advances in Sustainable Energy. Lecture Notes in Energy; Vasel-Be-Hagh, A., Ting, D., Eds.; Springer: Cham, Switzerland, 2019; Volume 70, pp. 113-132.

8. Burguet-Fernández, G.; Paredes-Sánchez, J.P.; Xiberta-Bernat, J. Bioenergy Valuation of Poultry Litter by Applying an Enzyme Product for Environmental Purposes: A New Applied Technology. Proceedings 2018, 2, 1480. [CrossRef]

9. Soutullo, S.; Giancola, E.; Sánchez, M.N.; Ferrer, J.A.; García, D.; Súarez, M.J.; Prieto, J.I.; Antuña-Yudego, E.; Carús, J.L.; Fernández, M.Á.; et al. Methodology for Quantifying the Energy Saving Potentials Combining Building Retrofitting, Solar Thermal Energy and Geothermal Resources. Energies 2020, 13, 5970. [CrossRef]

10. Paredes-Sánchez, J.P.; Conde, M.; Gómez, M.A.; Alves, D. Modelling hybrid thermal systems for district heating: A pilot project in wood transformation industry. J. Clean. Prod. 2018, 194, 726-734. [CrossRef]

11. Lake, A.; Rezaie, B.; Beyerlein, S. Review of district heating and cooling systems for a sustainable future. Renew. Sustain. Energy Rev. 2017, 67, 417-425. [CrossRef]

12. Benedek, J.; Sebestyén, T.T.; Bartók, B. Evaluation of renewable energy sources in peripheral areas and renewable energy-based rural development. Renew. Sustain. Energy Rev. 2018, 90, 516-535. [CrossRef]

13. Mohammadi, K.; Khanmohammadi, S.; Khorasanizadeh, H.; Powell, K. A comprehensive review of solar only and hybrid solar driven multigeneration systems: Classifications, benefits, design and prospective. Appl. Energy 2020, 268, 114940. [CrossRef]

14. Mahmoud, M.; Ramadan, M.; Naher, S.; Pullen, K.; Olabi, A.G. The impacts of different heating systems on the environment: A review. Sci. Total Environ. 2020, 766, 142625. [CrossRef]

15. Fernández, S.T.; Sánchez, J.P.P.; Trashorras, A.J.G. Analysis of forest residual biomass potential for bioenergy production in Spain. Clean Technol. Environ. Policy 2016, 18, 209-218.

16. Ma, Z.; Knotzer, A.; Billanes, J.D.; Jørgensen, B.N. A literature review of energy flexibility in district heating with a survey of the stakeholders' participation. Renew. Sustain. Energy Rev. 2020, 123, 109750. [CrossRef]

17. Mouaky, A.; Rachek, A. Thermodynamic and thermo-economic assessment of a hybrid solar/biomass polygeneration system under the semi-arid climate conditions. Renew. Energy 2020, 156, 14-30. [CrossRef]

18. Díaz-Cuevas, P.; Domínguez-Bravo, J.; Prieto-Campos, A. Integrating MCDM and GIS for renewable energy spatial models: Assessing the individual and combined potential for wind, solar and biomass energy in Southern Spain. Clean Technol. Environ. Policy 2019, 21, 1855-1869. [CrossRef]

19. Higueras-Castillo, E.; Munoz-Leiva, F.; Liébana-Cabanillas, F.J. An examination of attributes and barriers to adopt biomass and solar technology. A cross-cultural approach. J. Environ. Manag. 2019, 236, 639-648. [CrossRef] [PubMed]

20. Hussain, C.I.; Norton, B.; Duffy, A. Technological assessment of different solar-biomass systems for hybrid power generation in Europe. Renew. Sustain. Energy Rev. 2017, 68, 1115-1129. [CrossRef]

21. Zhang, L.; Li, F.; Sun, B.; Zhang, C. Integrated optimization design of combined cooling, heating, and power system coupled with solar and biomass energy. Energies 2019, 12, 687. [CrossRef]

22. Sahoo, U.; Kumar, R.; Singh, S.K.; Tripathi, A.K. Energy, exergy, economic analysis and optimization of polygeneration hybrid solar-biomass system. Appl. Therm. Eng. 2018, 145, 685-692. [CrossRef]

23. Igogo, T.; Lowder, T.; Engel-Cox, J.; Awuah-Offei, K.; Newman, A.M. Integrating Clean Energy in Mining Operations: Opportunities, Challenges, and Enabling Approaches (No. NREL/TP-6A50-76156); National Renewable Energy Lab. (NREL): Golden, CO, USA, 2020; p. 43.

24. Michalski, J.; Bünger, U.; Crotogino, F.; Donadei, S.; Schneider, G.S.; Pregger, T.; Cao, K.; Heide, D. Hydrogen generation by electrolysis and storage in salt caverns: Potentials, economics and systems aspects with regard to the German energy transition Int. J. Hydrog. Energy 2017, 42, 13427-13443. [CrossRef]

25. Paredes-Sánchez, J.P.; López-Ochoa, L.M.; López-González, L.M.; Xiberta-Bernat, J. Bioenergy for District Bioheating System (DBS) from eucalyptus residues in a European coal-producing region. Energy Convers. Manag. 2016, 126, 960-970. [CrossRef]

26. Paredes-Sánchez, J.P.; Míguez, J.L.; Blanco, D.; Rodríguez, M.A.; Collazo, J. Assessment of micro-cogeneration network in European mining areas: A prototype system. Energy 2019, 174, 350-358. [CrossRef]

27. Daioglou, V.; Doelman, J.C.; Wicke, B.; Faaij, A.; van Vuuren, D.P. Integrated assessment of biomass supply and demand in climate change mitigation scenarios. Glob. Environ. Change 2019, 54, 88-101. [CrossRef]

28. Wang, J.; Han, Z.; Guan, Z. Hybrid solar-assisted combined cooling, heating, and power systems: A review. Renew. Sustain. Energy Rev. 2020, 133, 110256. [CrossRef]

29. Liu, M.; van Dam, K.H.; Pantaleo, A.M.; Guo, M. Optimisation of integrated bioenergy and concentrated solar power supply chains in South Africa. Comput.-Aided Chem. Eng. 2018, 43, 1463-1468.

30. Bahlawan, H.; Morini, M.; Pinelli, M.; Poganietz, W.; Spina, P.; Venturini, M. Optimization of a hybrid energy plant by integrating the cumulative energy demand. Appl. Energy 2019, 253, 113484. [CrossRef] 
31. Wang, J.; Yang, Y. Energy, exergy and environmental analysis of a hybrid combined cooling heating and power system utilizing biomass and solar energy. Energy Convers. Manag. 2016, 124, 566-577. [CrossRef]

32. Srinivas, T.; Reddy, B.V. Hybrid solar-biomass power plant without energy storage. Case Stud. Therm. Eng. 2014, 2, 75-81. [CrossRef]

33. IRMC (Instituto Para la Reestructuración de la Minería del Carbón y de las Cuencas Mineras). Marco de Actuación para la Minería del Carbón y las Comarcas Mineras en el Periodo 2013-2018; IRMC: Madrid, Spain, 2014; p. 34. (In Spanish)

34. MINETUR (Ministerio de Industria, Energía y Turismo). Orden IET/1158/2014, de 30 de Junio, por la que se Aprueban las Bases Reguladoras para la Concesión de Ayudas Dirigidas a Proyectos Empresariales Generadores de Empleo, que Promuevan el Desarrollo Alternativo de las Zonas Mineras, para el Período 2014-2018; Ministerio de Industria, Energía y Turismo: Madrid, Spain, 2014. (In Spanish)

35. Raluy, R.G.; Guillén-Lambea, S.; Serra, L.M.; Guadalfajara, M.; Lozano, M.A. Environmental assessment of central solar heating plants with seasonal storage located in Spain. J. Clean Prod. 2021, 314, 128078. [CrossRef]

36. Paredes-Sánchez, B.M.; Paredes, J.P.; Caparrini, N.; Rivo-López, E. Analysis of District Heating and Cooling Energy Systems in Spain: Resources, Technology and Management. Sustainability 2021, 13, 5442. [CrossRef]

37. Van Holsbeeck, S.; Srivastava, S.K. Feasibility of locating biomass-to-bioenergy conversion facilities using spatial information technologies: A case study on forest biomass in Queensland, Australia. Biomass Bioenergy 2020, 139, 105620. [CrossRef]

38. Omar, R.C.; Wahab, W.A.; Putri, R.F.; Roslan, R.; Baharuddin, I.N.Z. Solar suitability map for office buildings using integration of remote sensing and Geographical Information System (GIS). In IOP Conference Series: Earth and Environmental Science; IOP Publishing: Bristol, UK, 2020; Volume 451, p. 012032.

39. Bergman, P.C.A.; Boersma, A.R.; Zwart, R.W.R.; Kiel, J.H.A. Torrefaction for Biomass Co-Firing in Existing Coal-Fired Power Stations; ECN (Energy Research Centre of the Netherlands): Petten, The Netherlands, 2005; pp. 1-71.

40. Avtar, R.; Sahu, N.; Aggarwal, A.K.; Chakraborty, S.; Kharrazi, A.; Yunus, A.P.; Dou, J.; Kurniawan, T.A. Exploring Renewable Energy Resources Using Remote Sensing and GIS-A Review. Resources 2019, 8, 149. [CrossRef]

41. PVGIS. Solar Energy Database. Available online: https://re.jrc.ec.europa.eu/pvg_tools/es/\#MR (accessed on 10 June 2021).

42. Censolar. Solar Technical Resources and Data. Available online: https:/ / www.censolar.org/energia-solar/ (accessed on 10 June 2021). (In Spanish).

43. Campus virtual. In La Energía Solar Térmica. Manual de Prácticas de Tecnología Energética (In Spanish), Database Solar for Practise Material; Universidad de Oviedo: Oviedo, Asturias, Spain, 2021.

44. BIORAISE. GIS Biomass Resources Database. Available online: http:/ / bioraise.ciemat.es/Bioraise (accessed on 10 June 2021).

45. Esteban, L.S.; Carrasco, J.E. Biomass resources and cost: Assessment in different EU countries. Biomass Bioenergy 2011, 35, S21-S30. [CrossRef]

46. MITECO (Ministerio para la Transición Ecológica y el Reto Demográfico). Plan de Energías Renovables (PER) 2011-2020, Primera Parte. Available online: https://www.miteco.gob.es/es/cambio-climatico/legislacion/documentacion/PER_2011-2020_VOL_ I_tcm30-178649.pdf (accessed on 18 June 2021). (In Spanish)

47. MITECO (Ministerio para la Transición Ecológica y el Reto Demográfico). Libro Energía en España 2017. Available online: https:/ / energia.gob.es/balances/Balances/LibrosEnergia/Libro-Energia-2017.pdf (accessed on 18 June 2021). (In Spanish)

48. Sánchez-Durán, R.; Luque, J.; Barbancho, J. Long-term demand forecasting in a scenario of energy transition. Energies 2019, 12, 3095. [CrossRef]

49. Hansen, K.; Vad Mathiesen, B. Comprehensive assessment of the role and potential for solar thermal in future energy systems. Sol. Energy 2018, 169, 144-152. [CrossRef]

50. Rämä, M.; Mohammadi, S. Comparison of distributed and centralised integration of solar heat in a district heating system. Energy 2017, 137, 649-660. [CrossRef]

51. Pauschinger, T. Solar thermal energy for district heating. In Advanced District Heating and Cooling (DHC) Systems; Wiltshire, R., Ed.; Woodhead Publishing: Cambridge, UK, 2015; pp. 99-120.

52. Duffie, J.A.; Beckman, W. Solar Engineering of Thermal Processes, 4th ed.; John Wiley \& Sons: Hoboken, NJ, USA, 2013 ; p. 944.

53. Klein, S.A.; Beckman, W.A.; Duffie, J.A. A Design Procedure for Solar Heating Systems. Sol. Energy 1976, 18, 113-126. [CrossRef]

54. Haberl, J.S.; Cho, S. Literature Review of Uncertainty of Analysis Methods (F-Chart Program), Report to the Texas Commission on Environmental Quality; Energy Systems Laboratory, Texas A\&M University: College Station, TX, USA, $2004 ;$ p. 17.

55. CHEQ4. Solar Energy Database and Software for Thermal Systems in Buildings. Available online: http://cheq4.idae.esMadrid (accessed on 10 June 2021). (In Spanish).

56. Solar District Heating (SDH). European Large Scale Solar Heating Plants Database. Available online: https://www.solar-districtheating.eu/en/plant-database/ (accessed on 10 November 2021).

57. Weiss, W.; Spörk-Dür, M. Solar Heat Worldwide-Global Market Development and Trends in 2019. Available online: https:/ / www.iea-shc.org/Data/Sites/1/publications/Solar-Heat-Worldwide-2020.pdf (accessed on 21 January 2021).

58. Heras-Saizarbitoria, I.; Sáez, L.; Allur, E.; Morandeira, J. The emergence of renewable energy cooperatives in Spain: A review. Renew. Sustain. Energy Rev. 2018, 94, 1036-1043. [CrossRef]

59. Pellet Asturias. Technical Report Database. Available online: http://www.pelletsasturias.com/es/productosyservicios.asp (accessed on 10 June 2021). 
60. Paredes, J.P. Estimación del Potencial Energético y del Efecto Sumidero de la Biomasa Forestal de Asturias. Ph.D. Thesis, University of Oviedo, Oviedo, Spain, 2010. (In Spanish)

61. García, R.; Pizarro, C.; Lavín, A.G.; Bueno, J.L. Spanish biofuels heating value estimation. Part I: Ultimate analysis data. Fuel 2014, 117, 1130-1138. [CrossRef]

62. Riaza, J.; Khatami, R.; Levendis, Y.A.; Álvarez, L.; Gil, M.V.; Pevida, C.; Rubiera, F.; Pis, J.J. Single particle ignition and combustion of anthracite, semi-anthracite and bituminous coals in air and simulated oxy-fuel conditions. Combust. Flame 2014, 161, 1096-1108. [CrossRef]

63. IDAE (Instituto para la Diversificación y Ahorro de la Energía). Consumos del Sector Residencial en España. Available online: https:/ / www.idae.es/uploads/documentos/documentos_Documentacion_Basica_Residencial_Unido_c93da537.pdf (accessed on 18 June 2021). (In Spanish)

64. Meyer, I.; Sommer, M.W. Employment Effects of Renewable Energy Supply-A Meta Analysis; Austrian Institute of Economic Research (WIFO): Vienna, Austria, 2014; p. 38.

65. Mäki, E.; Kannari, L.; Hannula, I.; Shemeikka, J. Decarbonization of a district heating system with a combination of solar heat and bioenergy: A techno-economic case study in the Northern European context. Renew. Energy 2021, 175, 1174-1199. [CrossRef]

66. Li, H.X.; Edwards, D.J.; Hosseini, M.R.; Costin, G.P. A review on renewable energy transition in Australia: An updated depiction. J. Clean. Prod. 2020, 242, 118475. [CrossRef]

67. Derčan, B.; Lukić, T.; Bubalo-Živković, M.; Durev, B.; Stojsavljević, R.; Pantelić, M. Possibility of efficient utilization of wood waste as a renewable energy resource in Serbia. Renew. Sustain. Energy Rev. 2012, 16, 1516-1527. [CrossRef]

68. Osmani, K.; Haddad, A.; Lemenand, T.; Castanier, B.; Ramadan, M. A review on maintenance strategies for PV systems. Sci. Total Environ. 2020, 746, 141753. [CrossRef]

69. Wolf, C.; Klein, D.; Richter, K.; Weber-Blaschke, G. Mitigating environmental impacts through the energetic use of wood: Regional displacement factors generated by means of substituting non-wood heating systems. Sci. Total Environ. 2016, 569-570, 395-403. [CrossRef]

70. Olave, R.J.; Forbes, E.G.A.; Johnston, C.R.; Relf, J. Particulate and gaseous emissions from different wood fuels during combustion in a small-scale biomass heating system. Atmos. Environ. 2017, 157, 49-58. [CrossRef]

71. López-Aparicio, S.; Vogt, M.; Schneider, P.; Kahila-Tani, M.; Broberg, A. Public participation GIS for improving wood burning emissions from residential heating and urban environmental management. J. Environ. Manag. 2017, 191, 179-188. [CrossRef] 